\title{
PENGARUH MODEL TIME TOKEN BERBASIS TRI HITA KARANA TERHADAP KOMPETENSI PENGETAHUAN IPA SISWA KELAS IV
}

\author{
${ }^{1} \mathrm{Ni}$ Made Eva Suryantari, ${ }^{2} \mathrm{I}$ Nengah Suadnyana, ${ }^{3} \mathrm{I}$ Gst. Agung Ayu Wulandari \\ ${ }^{1,2,3}$ Prodi Pendidikan Guru Sekolah Dasar, Universitas Pendidikan Ganesha, Indonesia \\ email:made.eva.suryantari@undiksha.ac.id1,inengah.suadnyana@undiksha.ac.i \\ d2, ayu.wulandari@undiksha.ac.id3
}

\begin{abstract}
ABSTRAK
Penelitian ini bertujuan untuk mengetahui pengaruh model pembelajaran Time Token berbasis Tri Hita Karana terhadap kompetensi pengetahuan IPA siswa kelas IV SDN Gugus Dewi Sartika. Jenis penelitian ini adalah penelitian eksperimen semu dengan rancangan penelitian nonequivalent control grup desain. Populasi penelitian meliputi seluruh kelas IV di SDN Gugus Dewi Sartika sebanyak 331 siswa. Sampel penelitian adalah siswa kelas IVA SDN 3 Kesiman dengan jumlah 36 siswa sebagai kelompok eksperimen dan siswa kelas IVA SDN 10 Kesiman dengan jumlah 33 siswa sebagai kelompok kontrol yang diperoleh dengan teknik random sampling. Pengumpulan data dilakukan dengan metode tes dengan bentuk tes objektif pilihan ganda biasa. Data dianalisis menggunakan uji-t (polled varians) melalui uji hipotesis diperoleh thitung $=3,813>$ ttabel $=2,000$ dengan $\mathrm{dk}=67$ dan taraf signfikansi $5 \%$ berdasarkan hasil analisis data diperoleh rata-rata gain skor ternormalisasi kelompok eksperimen $1=0,412>2=0,290$ untuk kelompok kontrol. Berdasarkan kriteria pengujian maka, Ho ditolak. Ini berarti terdapat perbedaan yang signifikan penguasaan kompetensi pengetahuan IPA antara kelompok siswa yang dibelajarkan melalui model pembelajaran Time Token berbasis Tri Hita Karana dengan kelompok siswa yang dibelajarkan melalui pembelajaran konvensional. Dengan demikian dapat disimpulkan bahwa model pembelajaran Time Token berbasis Tri Hita Karana berpengaruh terhadap kompetensi pengetahuan IPA siswa kelas IV SDN Gugus Dewi Sartika. Berdasarkan hasil penelitian disarankan bahwa hasil penelitian ini dapat dijadikan sebagai kajian yang relevan khususnya sebagai penunjang penelitian selanjutnya mengenai model pembelajaran Time Token berbasis Tri Hita Karana.
\end{abstract}

Kata kunci: Time Token, Tri Hita Karana, kompetensi IPA

\begin{abstract}
This study aims to determine the effect of Tri Hita Karana based Time Token learning model on science knowledge competencies of fourth grade students of SDN Cluster Dewi Sartika Academic Year 2018/2019. This type of research is quasi-experimental research with a nonequivalent control design group design. The study population included all of the fourth grade in SDN Gugus Dewi Sartika as many as 331 students. The research sample was grade IVA students of SDN 3 Kesiman with 36 students as experimental groups and IVA graders SDN 10 Kesiman with 33 students as a control group obtained by random sampling technique. Data collection was carried out by the test method with the usual multiple choice objective test. Data were analyzed using t-test (polled variance) through hypothesis testing obtained thitung $=3.813>\mathrm{t}$ table $=2,000$ with $\mathrm{dk}=67$ and significance level of $5 \%$ based on the results of data analysis obtained average gain normalized score of experimental group 1 $=0.412>2=0.290$ for the control group. Based on the testing criteria, Ho is rejected. This
\end{abstract}


means that there is a significant difference in the mastery of science knowledge competencies between groups of students who are taught through the Tri Hita Karana-based Time Token learning model and groups of students who are taught through conventional learning. Thus it can be concluded that the Time Token learning model based on Tri Hita Karana influences the science competency of fourth grade students of SDN Gugus Dewi Sartika in the academic year 2018/2019. Based on the results of the study, it is suggested that the results of this study can be used as relevant studies, especially as supporting further research on the Time Token learning model based on Tri Hita Karana.

Keywords : Time Token, Tri Hita Karana, science competence

\section{PENDAHULUAN}

Pesatnya perkembangan ilmu pengetahuan dan teknologi pada zaman globalisasi ini, secara tidak langsung menuntut kesadaran manusia untuk dapat beradaptasi dan meningkatkan kualitasnya. Untuk menjawab tantangan zaman, tidak dapat dipungkiri bahwa keberadaan pendidikan menjadi kebutuhan utama yang memberikan kontribusi besar dalam upaya untuk memberikan bekal kemampuan bagi manusia baik dari segi intelektualitas maupun pengembangan keterampilan dan potensi manusia, sehingga manusia dapat meningkatkan kualitas dirinya.

Dalam penyelenggaraan pendidikan di Indonesia sendiri ditetapkan jenjang-jenjang pendidikan bagi peserta didik, yaitu diantaranya adalah pendidikan anak usia dini, pendidikan anak sekolah dasar, pendidikan sekolah menengah pertama, pendidikan sekolah menengah atas, hingga sampai pada perguruan tinggi. Dari beberapa jenjang pendidikan tersebut, salah satu jenjang pendidikan yang memegang peranan penting yaitu pendidikan anak sekolah dasar.

Pendidikan anak sekolah dasar merupakan jenjang pendidikan yang berperan penting dalam membentuk keterampilan serta kemampuan dasar peserta didik dalam berbagai aspek pengetahuan, dan menjadi bagian dari proses dimulainya seseorang dalam menempuh dunia pendidikan. Salah satu tujuan pendidikan nasional yaitu mencerdaskan kehidupan bangsa. Untuk mencerdaskan kehidupan bangsa salah satunya dapat ditempuh melalui jalur pendidikan formal. Pelaksanaan pendidikan di lembaga-lembaga pendidikan formal berpedoman pada kurikulum yang telah ditetapkan.

UU RI No. 20 Tahun 2003 Tentang Sistem Pendidikan Nasional menyatakan bahwa kurikulum merupakan seperangkat rencana dan pengaturan mengenai tujuan, isi, dan bahan pelajaran serta cara yang digunakan sebagai pedoman penyelenggaraan kegiatan pembelajaran untuk mencapai tujuan pendidikan tertentu. Sebagai pedoman penyelenggaraan kegiatan pembelajaran sangat berperan dalam mengarahkan pembelajaran agar dapat mencapai tujuan pendidikan tertentu, untuk itu pembaharuan terhadap kurikulum terus dilakukan. Pembaharuan kurikulum dimaknai sebagai upaya untuk mendukung pendidikan agar dapat beradaptasi dengan berbagai perkembangan zaman. Kurikulum yang mulai serempak ditetapkan di Indonesia sejak tahun 2013 hingga saat ini adalah Kurikulum 2013.

Pembelajaran pada kurikulum 2013 menggunakan pendekatan saintifik. Kosasih (2016:72) menyatakan, pendekatan saintifik merupakan pendekatan di dalam kegiatan pembelajaran yang mengutamakan kreativitas dan temuan siswa. Pengalaman belajar yang mereka peroleh tidak bersifat indoktrinisasi, hafalan, dan sejenisnya. Pengalaman belajar, baik itu yang berupa pengetahuan, keterampilan, dan sikap mereka peroleh berdasarkan kesadaran dan kepentingan mereka sendiri. Namun Jika dalam proses pembelajaran hanya 
diterapkan dengan menggunakan pendekatan saintifik, maka pembelajaran akan menjadi kurang efektif dalam mencapai suatu tujuan pembelajaran. Sehingga dalam proses pembelajaran siswa akan menjadi cepat bosan pada saat mengikuti proses pembelajaran karena pembelajaran terkesan monoton. Maka dari itu, untuk mengoptimalkan tujuan pembelajaran yang akan disampaikan dapat dilakukan dengan menggunanakan model pembelajaran yang inovatif yang sesuai dengan karakteristik siswa secara maksimal. Sehingga diharapkan hasil kompetensi pengetahuan siswa akan tercapai dengan baik, khususnya kompetensi pengetahuan IPA.

IImu Pengetahuan Alam atau yang biasa disebut IPA merupakan salah satu muatan materi yang terdapat pada kurikulum 2013 yang dapat mengukur kompetensi pengetahuan siswa. IPA adalah "usaha manusia dalam memahami alam semesta melalui pengamatan yang tepat pada sasaran, serta menggunakan prosedur, dan dijelaskan dengan penalaran sehingga mendapat suatu kesimpulan" (Susanto, 2015:167). Sedangkan menurut Wisudawati dan Sulistyowati (2017:22) berpendapat "IPA memiliki karakteristik khusus yang mempelajari fenomena alam yang faktual (factual), baik berupa kenyataan (reality) atau kejadian (events) dan hubungan sebab-akibatnya". Dari beberapa pendapat para ahli, dapat dirangkum bahwa IPA adalah kumpulan teori yang sistematis tentang usaha manusia dalam memahami gejala-gejala alam semesta melalui pengamatan dan hasil percobaan yang tepat sasaran serta menggunakan prosedur, dan dijelaskan dengan penalaran sehingga mendapatkan suatu kesimpulan.

Adapun tujuan dari mata pelajaran IPA di Sekolah Dasar menurut Susanto (2015: 171) adalah 1) Memperoleh keyakinan terhadap kebesaran Tuhan Yang Maha Esa berdasarkan keberadaan, keindahan,dan keteraturan alam ciptaan-Nya, 2) Mengembangkan pengetahuan dan pemahaman konsep-konsep IPA yang bermanfaat dan dapat diterapkan dalam kehidupan sehari-hari, 3) Mengembangkan rasa ingin tahu, sikap positif dan kesadaran tentang adanya hubungan yang paling memengaruhi antara IPA, lingkungan, teknologi, dan masyarakat, 4) Mengembangkan keterampilan proses untuk menyelidiki alam sekitar, memecah masalah, dan membuat keputusan, 5) Meningkatkan kesadaran untuk berperan secara dalam memelihara, menjaga, dan melestrikan lingkungan alam, 6) Meningkatkan kesadaran untuk menghargai alam dan segala keteraturannya sebagai salah satu ciptaan Tuhan.

Menurut Hal dan Jones (dalam Kosasih, 2016:13) menyatakan bahwa "kompetensi adalah pernyataan yang menggambarkan penampilan suatu kemampuan tertentu secara bulat, sebagai perpaduan pengetahuan dari kemampuan tertentu secara bulat, sebagai perpaduan pengetahuan dari kemampuan yang dapat diamati dan diukur". Sedangkan Richards (dalam Kosasih, 2016:13) menyatakan bahwa "kompetensi adalah perilaku yang dapat diamati, yang diperlukan untuk menuntaskan kegiatan sehari-hari dengan berhasil". Selanjutnnya menurut Kosasih (2016:14) kompetensi merupakan sesuatu yang kompleks, yang didalamnya mengandung banyak aspek (ranah). Berdasarkan beberapa pengertian tersebut dapat dirangkum bahwa kompetensi adalah pernyataan yang menggambarkan tentang kemampuan bersikap, menggunakan pengetahuan dan keterampilan yang dimiliki oleh seseorang yang dapat diamati dan diukur.

Kompetensi pengetahuan khususnya pada muatan materi IPA merupakan perubahan perilaku siswa yang mencerminkan kemampuan siswa terhadap penguasaan materi mata pelajaran IPA. Dengan mempelajari IPA siswa dapat mengetahui tentang makhluk hidup dan alam sekitar yang dekat dengan kehidupannya. Selain itu, dengan mempelajari IPA siswa diharapkan mampu menerapkannya dalam kehidupan sehari-hari 
maupun dalam dunia kerja, oleh karena itu muatan materi IPA di sekolah dasar merupakan salah satu muatan materi yang diaanggap sangat penting dan harus dikuasai oleh siswa.

Dalam proses pembelajaran, kompetensi pengetahuan IPA siswa dapat dipengaruhi oleh dua faktor yaitu faktor internal dan eksternal. Faktor internal meliputi minat dan motivasi siswa terhadap mata pelajaran IPA. Sedangkan faktor eksternal yang dapat memengaruhi kompetensi pengetahuan IPA adalah lingkungan sekolah. Di lingkungan sekolah, guru memiliki peranan penting dalam proses pembelajaran.

Pada kenyataannya, masih banyak siswa yang belum menguasai muatan materi IPA karena dianggap muatan materi yang sulit. Berdasarkan hasil observasi yang dilakukan di SDN Gugus Dewi Sartika khususnya pada mata pelajaran IPA kelas IV, ditemukan bahwa masih kurangnya antusias dan partisipasi siswa saat mengikuti pembelajaran. Siswa kurang bersemangat dan aktif dalam mengikuti pembelajaran. Selain itu, guru masih belum maksimal dalam menerapkan model pembelajaran dikarenakan di sekolah masih diterapkannya model pembelajaran konvensional. Pembelajaran konvensional yang dilakukan di sekolah dasar adalah pembelajaran yang dilakukan guru sehari-hari yang lebih didominasi oleh guru dan cenderung monoton tanpa adanya variasi dalam penyampaian materi. Sekolah belum melaksanakan pembelajaran yang inovatif, proses pembelajaran menjadi kurang menarik yang menyebabkan siswa menjadi cepat bosan dan cenderung bersikap pasif serta merasa takut atau malu dalam mengemukakan pendapatnya dalam proses pembelajaran, sehingga pembelajaran menjadi kurang menyenangkan dan terasa sulit. Proses pembelajaran yang monoton membuat siswa kurang fokus dan cepat jenuh sehingga kompetensi pengetahuan IPA siswa belum tercapai secara optimal. Kompetensi pengetahuan IPA siswa masih perlu ditingkatan dan dioptimalkan lagi untuk mendapatkan nilai yang lebih baik.

Permasalahan tersebut menjadikan guru harus selektif dalam memilih model pembelajaran yang dapat menyajikan mata pelajaran IPA dengan kreatif dan menarik sehingga dapat menghilangkan kebosanan pada siswa, meningkatkan minat belajar, keaktifan serta dapat mengoptimalkan kompetensi pengetahuan IPA.

Ada berbagai model pembelajaran inovatif yang bisa digunakan dalam pelaksanaan pembelajaran salah satu model pembelajaran yang dapat digunakan yaitu dengan menerapkan model pembelajaran Time Token. Menurut Kurniasih dan Sani (2016: 107) Time Token merupakan salah satu contoh kecil dari penerapan pembelajaran demokratis di sekolah. Proses pembelajaran demokratis adalah proses belajar yang menempatkan siswa sebagai subjek. Sepanjang proses belajar, aktivitas siswa menjadi titik perhatian utama. Dengan kata lain mereka selalu dilibatkan secara aktif. Guru berperan mengajak siswa mencari solusi bersama terhadap permasalahan yang ditemui. Kemudian Chotimah dan Fathurrohman (2018: 300) menyatakan bahwa model ini digunakan untuk melatih dan mengembangkan keterampilan sosial, agar peserta didik tidak mendominasi pembicaraan atau siswa diam sama sekali. Dari beberapa pengertian tersebut dapat dirangkum bahwa model pembelajaran Time Token merupakan suatu pembelajaran demokratis yang digunakan untuk melatih siswa agar tidak terlalu mendominasi pembicaraan atau diam sama sekali.

Guru memberi sejumlah kupon berbicara dengan waktu kurang lebih 30 detik per kupon pada tiap siswa. Sebelum berbicara, siswa menyerahkan kupon terlebih dahulu pada guru. Satu kupon adalah untuk satu kesempatan berbicara. Siswa dapat tampil lagi setelah bergiliran dengan siswa lainnya. Siswa yang telah habis kuponnya tidak boleh bicara lagi. Siswa yang masih memegang kupon harus bicara sampai semua kuponnya habis. 
Menurut Chotimah dan Fathurrohman (2018) Kelebihan dari model pembelajaran Time Token adalah : 1) Mendorong peserta didik untuk meningkatkan inisiatif dan partisipasinya. 2) Tidak ada peserta didik yang mendominasi pemberbicaraan atau diam sama sekali. 3) Melatih peserta didik untuk mengungkapkan pendapatnya. 4) Menumbuhkan kebiasaan pada peserta didik untuk saling mendengarkan, berbagi, memberikan masukan, dan memiliki sikap keterbukaan terhadap kritik. 5) Mengajarkan peserta didik untuk menghargai pendapat orang lain. 6) Tidak memerlukan banyak media pembelajaran.

Model pembelajaran Time Token adalah model pembelajaran yang bertujuan agar masing-masing anggota kelompok diskusi mendapatkan kesempatan untuk memberikan kontribusi dalam menyampaikan pendapatnya dan mendengarkan pandangan serta pemikiran anggota lain. Dengan penggunaan model pembelajaran Time Token ini dimaksudkan sebagai alternatif untuk megembangkan keterampilan sosial yang bertujuan untuk menghindari peserta didik diam sama sekali dan menghendaki peserta didik saling membantu dalam kelompok kecil.

Di era globalisasi seperti sekarang ini kemajuan IPTEK dan pengaruh nilai sosial budaya dari negara barat sangat berpengaruh pada pola pikir dan prilaku sebagian masyarakat terutama generasi muda, sehingga diperlukan suatu pembelajaran yang tetap memunculkan nilai lokal, salah satunya Tri Hita Karana. "Tri Hita Karana merupakan ajaran yang mengajarkan umat manusia untuk menciptakan hubungan yang harmonis dengan Tuhan, dengan sesama manusia dan dengan alam lingkungan, maka akan terwujud kehidupan yang bahagia lahir batin" (Wiana, 2007:5). Menurut Atmaja, dkk (2010:60) "Tri Hita Karana berasal dari kata 'Tri' yang berarti tiga 'Hita' yang berarti kebahagiaan dan 'Karana' yang berarti penyebab. Dengan demikian Tri Hita Karana berarti tiga penyebab terciptanya kebahagiaan". Berdasarkan pendapat tersebut dapat disimpulkan bahwa Tri Hita Karana berarti tiga unsur penyebab kebahagiaan dan kesejahteraan manusia yang bersumber dari adanya hubungan yang harmonis antara manusia dengan Tuhan Yang Maha Esa, hubungan baik manusia dengan manusia lainnya, serta hubungan baik manusia dengan lingkungannya. Dalam hal ini, siswa diajarkan untuk selalu bersyukur, untuk menghargai pendapat temannya, kerjasama di dalam kelompok dan interaksi dengan kelompok lain. Dengan demikian hubungan harmonis dengan Tuhan, dengan sesama manusia dan dengan alam lingkungan dapat tercipta dengan baik.

Model pembelajaran Time Token berbasis Tri Hita Karana merupakan perpaduan antara model pembelajaran yang memberikan kesempatan kepada masing-masing anggota kelompok diskusi untuk memberikan kontribusi dalam menyampaikan pendapatnya dan mendengarkan pandangan serta pemikiran anggota lain dan dibarengi dengan pengamalan nilai-nilai kearifan lokal Tri Hita Karana. Dengan menggunakan model Time Token berbasis Tri Hita Karana dapat menumbuhkan perilaku adil antara setiap siswa karena seluruh siswa mempunyai kesempatan berbicara, sehingga tidak ada siswa yang mendominasi di dalam kelompok. model pembelajaran Time Token berbasis Tri Hita Karana dapat melatih siswa agar tidak terlalu mendominasi pembicaraan atau diam sama sekali, dengan berbasis Tri Hita Karana yang mengutamakan hubungan harmonis, maka mempermudah pemahaman siswa mengenai materi pembelajaran, sehingga pencapaian kompetensi pengetahuan IPA siswa menjadi optimal.

Adapun tujuan dari penelitian ini yakni pertama, untuk mendeskripsikan kompetensi pengetahuan IPA kelompok siswa yang dibelajarkan dengan model pembelajaran Time Token berbasis Tri Hita Karana pada siswa kelas IV SDN Gugus Dewi Sartika Denpasar Timur. Kedua, untuk mendeskripsikan kompetensi pengetahuan IPA kelompok siswa yang dibelajarkan melalui pembelajaran konvensional pada siswa kelas IV SDN Gugus Dewi 
Sartika Denpasar Timur. Dan ketiga, Untuk mengetahui perbedaan yang signifikan kompetensi pengetahuan IPA antara kelompok siswa yang dibelajarkan melalui model pembelajaran Time Token berbasis Tri Hita Karana dengan kelompok siswa yang dibelajarkan melalui pembelajaran konvensional pada siswa kelas IV SDN Gugus Dewi Sartika Denpasar Timur.

\section{METODE}

Penelitian ini menggunakan rancangan penelitian kuantitatif dengan desain eksperimental yaitu quasi eksperiment (Eksperimen Semu). Bentuk desain yang digunakan dalam penelitian ini adalah rancangan kelompok Nonequivalent control group design. Menurut Setyosari (2015:221) Populasi merupakan keseluruhan dari objek, orang, peristiwa, atau sejenisnya yang menjadi perhatian dan kajian dalam penelitian. Sedangkan menurut Sugiyono (2015:117) populasi adalah wilayah generalisasi yang terdiri atas: obyek/subyek yang mempunyai kualitas dan karakteristik tertentu yang ditetapkan oleh peneliti untuk di pelajari dan kemudian ditarik kesimpulannya. Prosedur penelitian yang akan dilaksanakan dalam penelitian ini terdiri atas tiga tahapan, yaitu tahap persiapan, pelaksanaan, dan pengakhiran eksperimen.

Populasi dalam penelitian ini adalah siswa kelas IV di SDN yang terdapat di Gugus Dewi Sartika Denpasar Timur yang berjumlah 9 kelas dengan jumlah siswa sebanyak 331. Menurut Cohen (dalam Setyosari, 2015:221) sampel adalah suatu kelompok yang lebih kecil atau bagian dari populasi secara keseluruhan. Sampel itu merupakan sejumlah kelompok kecil yang mewakili populasi untuk dijadikan sebagi objek penelitian. Menurut Sugiyono (2015:118) "sampel adalah bagian dari jumlah dan karakteristik yang dimiliki oleh populasi".

Teknik sampling yang digunakan pada penelitian ini adalah menggunakan sampel acak atau random sampling dengan cara pengundian. Setelah diundi mendapat dua kelas yang menjadi sampel penelitian. Setelah mendapat dua sampel maka kedua sampel yang terpilih akan diberikan pretest untuk penyetaraan sampel. Skor dari hasil pretest dianalisis menggunakan uji-t untuk mengetahui bahwa kemampuan kedua sampel setara secara akademik. Setelah diketahui kedua kelompok sampel setara, maka dilakukan pengundian tahap kedua dari kedua sampel yang setara untuk memilih nama sekolah yang digunakan sebagai kelompok eksperimen dan kelompok kontrol. Makan diperoleh kelas eksperimen yaitu kelas IVA SDN 3 Kesiman dengan jumlah 36 siswa yang dibelajarkan menggunakan model pembelajaran Time Token berbasis Tri Hita Karana dan kelas kontrol yaitu kelas IVA SDN 10 Kesiman dengan jumlah 33 siswa yang dibelajarkan dengan pembelajaran konvensional.

Dalam penelitian ini, metode pengumpulan data yang digunakan adalah metode tes. Menurut Arikunto (2015:67) "tes merupakan alat atau prosedur yang digunakan untuk mengetahui atau mengukur sesuatu dalam suasana, dengan cara dan aturan-aturan yang sudah ditentukan". Instrument yang digunakan untuk mengumpulkan data kompetensi pengetahuan IPA siswa adalah tes objektif pilihan ganda biasa. Arikunto (2015:179) mengemukakan bahwa "tes objektif adalah tes yang dalam pemeriksaanya dapat dilakukan secara objektif". Pada umumnya alternatif jawaban berkisar antara 4 atau 5 option. Tes yang telah disusun kemudian diujicobakan untuk mendapatkan gambaran tentang kelayakan tes tersebut.

Sebelum digunakan dalam penelitian, instrumen penelitian terlebih dahulu divalidasi secara teoritis dari segi validitas isinya. Untuk menentukan validitas isi dilakukan dengan cara melakukan analisis kurikulum, buku pelajaran, dan kisi-kisi soal. Agar memenuhi syarat sebagai instrumen penelitian yang baik, selain melakukan hal tersebut, validitas isi 
instrumen dilakukan dengan pertimbangan pakar (expert judges). Sebagai pakar dalam memvalidasi instrumen penelitian ini adalah seorang dosen pembimbing yang telah berkualifikasi magister dan seorang guru yang telah berkualifikasi ahli madya pendidikan. Pertimbangan-pertimbangan yang diberikan oleh pakar, bahwa butir-butir tes telah representatif dalam konstruksi instrumen ditinjau dari validitas isi.

Selanjutnya instrumen penelitian diuji validitas butir soal, reliabilitasnya, daya beda dan indeks kesukaran. Hal ini dilakukan untuk mendapatkan gambaran apakah instrumen kompetensi pengetahuan IPA layak digunakan sebagai instrumen penelitian. Uji coba instrumen tes kompetensi pengetahuan IPA dilakukan di Kelas VB SDN 3 Kesiman yang diikuti oleh 42 siswa. Instrumen tes kompetensi IPA yang diujicobakan berjumlah 50 butir soal. Dari hasil validasi instrumen sebanyak 50 butir soal yang diujicobakan tersebut diperoleh 30 butir soal yang valid, sehingga butir soal yang digunakan dalam penelitian berjumlah 30 soal dengan reliabilitas tes $r 11=0,90$ yang berarti tes tersebut reliable.

Dalam penelitian ini data yang terkumpul akan dianalisis menggunakan metode analisis statistik deskriptif dan metode analisis statistik inferensial. Data yang digunakan untuk melakukan analisis pada penelitian ini adalah dengan menggunakan data gain skor yang dinormalisasi dari hasil pretest dan hasil posttest yang telah didapatkan. Skor pretest dan posttes diambil dari sampel penelitian. Penyajian data yang digunakan dalam statistik deskriptif ini adalah melalui rata-rata (mean), standar deviasi (SD) dan varians. Setelah mendapatkan data mengenai rata-rata nilai siswa kedua kelompok, selanjutnya data tersebut dianalisis dan dikonversikan kedalam kriteria peningkatan gain skor.

Dalam uji statistik inferensial, terlebih dahulu dilakukan uji prasyarat analisis yang meliputi uji normalitas dan homogenitas varians. Setelah data berdistribusi normal dan homogen makaselanjutnya dilakukan uji hipotesis dengan menggunakan uji-t dengan rumus polled varians.

\section{HASIL DAN PEMBAHASAN}

Data yang diperoleh dalam penelitian ini dikelompokkan menjadi dua yaitu, data kompetensi pengetahuan IPA kelompok eksperimen yang dibelajarkan dengan model pembelajaran Time Token berbasis Tri Hita Karana dan data kompetensi pengetahuan IPA kelompok kontrol yang dibelajarkan dengan pembelajaran konvensional. Siswa terlebih dahulu diberikan pretest untuk mengukur kompetensi pengetahuan IPA awal siswa. Setelah diberikan pretest dilanjutkan dengan pemberian perlakuan atau treatment sebanyak 6 kali. Pada akhir penelitian siswa diberikan posttest untuk memperoleh data kompetensi pengetahuan IPA siswa. Setelah memperoleh skor posttest kemudian dicari gain skor yang dinormalisasikan dari hasil pretest dan posttest.

Rincian hasil perhitungan nilai rata-rata, standar deviasi, dan varians dari data gain skor ternormalisasi kompetensi pengetahuan IPA pada kelompok siswa yang dibelajarkan melalui model pembelajaran Time Token berbasis Tri Hita Karana disajikan dalam tabel sebagai berikut.

Tabel 1. Deskripsi Data Gain Skor Ternormalisasi Kompetensi Pengetahuan IPA Kelompok Eksperimen 
Ni Made Eva Suryantari, I Nengah Suadnyana, I Gst. Agung Ayu Wulandari. (2018). Jurnal Pendidikan Multikultural Indonesia. Vol. 1 (2) pp. 62-72.

\begin{tabular}{lc}
\hline Rata-rata (mean) & 0,412 \\
\hline Standar Deviasi & 0,138 \\
\hline Varians & 0,019 \\
\hline
\end{tabular}

Berdasarkan hasil perhitungan deskriptif data gain skor ternormalisasi kompetensi pengetahuan IPA kelompok eksperimen yang berjunlah 36 siswa, diketahui rata-rata (mean) $(=0,412$, standar deviasi kelompok $=0,138$, varians $=0,019$. Selanjutnya rata-rata gain skor kompetensi pengetahuan IPA kelompok eksperimen $(=0,412$ dianalisis atau dikonversikan kedalan kriteria peningkatan gain skor, sehingga dapat diketahui kompetensi pengetahuan IPA siswa kelompok eksperimen berada pada kategori Sedang.

Sedangkan rincian hasil perhitungan nilai rata-rata, standar deviasi, dan varians dari data gain skor ternormalisasi kompetensi pengetahuan IPA pada kelompok siswa yang dibelajarkan melalui pembelajaran konvensional disajikan dalam tabel sebagai berikut.

Tabel 2. Deskripsi Data gain skor Kompetensi Pengetahuan IPA Kelompok Kontrol

\begin{tabular}{lc}
\hline Rata-rata (mean) & 0,290 \\
\hline Standar Deviasi & 0,133 \\
\hline Varians & 0,018 \\
\hline
\end{tabular}

Berdasarkan hasil perhitungan deskriptif data gain skor ternormalisasi kompetensi pengetahuan IPA kelompok kontrol yang berjumlah 33 siswa, diketahui rata-rata (mean) ( = 0,290 , standar deviasi $=0,133$, varians $=0,018$. Selanjutnya rata-rata gain skor kompetensi pengetahuan IPA kelompok kontrol ( $=0,290$ dianalisis atau dikonversikan kedalan kriteria peningkatan gain skor, Sehingga dapat diketahui kompetensi pengetahuan IPA siswa kelompok kontrol berada pada kategori Rendah.

Sebelum dilakukannya uji hipotesis dengan menggunakan uji-t, terlebih dahulu data kompetensi pengetahuan IPA yang diperoleh pada kelompok eksperimen dan kelompok kontrol harus dilakukan uji prasyarat analisis yang meliputi uji normalitas dan homogenitas data. Uji normalitas data dilakukan pada kelompok eksperimen dan kelompok kontrol. Berdasarkan uji normalitas sebaran data kelompok eksperimen, diperoleh harga nilai maksimum |FT - FS $\mid=0,135$. Dan harga nilai tabel Kolmogorov-Smirnov untuk taraf signifikansi $5 \%$ dengan $n=36$ diperoleh harga nilai tabel Kolmogorov-Smirnov $=0,221$. Oleh karena harga nilai maksimum $|\mathrm{FT}-\mathrm{FS}|=0,135<$ harga nilai tabel KolmogorovSmirnov $=0,221$. maka dapat disimpulkan bahwa data kompetensi pengetahuan IPA pada kelompok eksperimen berdistribusi normal.

Sedangkan berdasarkan uji normalitas sebaran data kelompok kontrol, diperoleh harga nilai maksimum $\mid F T$ - FS $\mid=0,131$. Dan harga nilai tabel Kolmogorov-Smirnov untuk taraf signifikansi $5 \%$ dengan $\mathrm{n}=33$ diperoleh harga nilai tabel Kolmogorov-Smirnov = 0,231 . Oleh karena harga nilai maksimum $\mid F T$ - FS $\mid=0,131<$ harga nilai tabel Kolmogorov-Smirnov $=0,231$. Maka dapat disimpulkan bahwa data kompetensi pengetahuan IPA pada kelompok kontrol berdistribusi normal. 
Selanjutnya dilakukan uji homogenitas varians. Berdasarkan perhitungan homogenitas varians diperoleh Fhitung $=1,06$ sedangkan pada taraf signifikansi $5 \%$ dengan derajat kebebasan pembilang $36-1=35$ dan derajat kebebasan penyebut $33-1=32$ diperoleh Ftabel $=1,76$. Oleh karena harga Fhitung $=1,06<$ harga Ftabel $=1,76$, maka Ho diterima dan data gain skor ternormalisasi kompetensi pengetahuan IPA antara kelompok eksperimen dan kelompok kontrol mempunyai varians yang homogen.

Pengujian hipotesis dilakukan untuk menguji hipotesis penelitian yang diajukan. Hipotesis yang diuji dalam penelitian ini adalah Ho : Tidak terdapat perbedaan yang signifikan kompetensi pengetahuan IPA antara kelompok siswa yang dibelajarkan melalui model pembelajaran Time Token berbasis Tri Hita Karana dengan kelompok siswa yang dibelajarkan melalui pembelajaran konvensional pada kelas IV SDN Gugus Dewi Sartika Denpasar Timur.

Berdasarkan hasil uji normalitas dan homogenitas dapat diketahui bahwa data yang diperoleh dari kelompok eksperimen dan kelompok kontrol berdistribusi normal dan memiliki varians yang homogen. Dengan demikian, uji hipotesis menggunakan uji-t dapat dilakukan. Analisis statistik yang digunakan untuk menguji hipotesis penelitian ini adalah uji-t dengan rumus polled varians. Rekapitulasi hasil uji-t dari data gain skor ternormalisasi kompetensi pengetahuan IPA siswa disajikan pada tabel sebagai berikut.

Tabel 3. Rekapitulasi hasil uji-t dari data gain skor ternormalisasi kompetensi pengetahuan IPA

\begin{tabular}{|llllll|}
\hline No & Kelompok Sampel & $\mathrm{N}$ & $\mathrm{Dk}$ & thitung ttabel \\
\hline 1 & Eksperimen & 36 & 67 & 3,813 & 2,000 \\
\hline 2 & Kontrol33 & & & & \\
\hline
\end{tabular}

Hasil analisis uji-t diperoleh thitung $=3,813$. Harga tersebut kemudian dibandingkan dengan harga ttabel dengan $\mathrm{dk}=36+33-2=67$ dan taraf signifikansi $5 \%$ sehingga diperoleh ttabel $=2,000$ karena thitung $=3,813>$ ttabel $=2,000$ maka Ho ditolak. Hal ini berarti terdapat perbedaan yang signifikan kompetensi pengetahuan IPA kelompok siswa yang dibelajarkan melalui model pembelajaran Time Token berbasis Tri Hita Karana dengan kelompok siswa yang dibelajarkan melalui pembelajaran konvensional siswa kelas IV SDN Gugus Dewi Sartika Denpasar Timur .

Perolehan hasil perhitungan analisis data menunjukkan bahwa rata-rata gain skor ternormalisasi kompetensi pengetahuan IPA siswa yang mengikuti pembelajaran menggunakan model Time Token berbasis Tri Hita Karana lebih tinggi dari rata rata gain skor kompetensi pengetahuan IPA siswa yang mengikuti pembelajaran konvensional ( eksperimen $=0,412>$ kontrol $=0,290$ ). Dengan demikian, Time Token berbasis Tri Hita Karana dapat direkomendasikan dalam membelajarkan siswa khususnya pada kegiatan pembelajaran bermuatan materi IPA.

Dari perolehan kompetensi pengetahuan pada kedua kelompok dapat diketahui bahwa kedua kelompok yang awalnya memiliki kemapuan yang setara, kemudian setelah diberikan perlakuan pada kelompok eksperimen dengan model pembelajaran Time Token berbasis Tri Hita Karana maka perolehan nilai kompetensi pengetahuan IPA mengalami perbedaan yang signifikan. Kompetensi pengetahuan IPA siswa pada kelompok eksperimen lebih baik apabila dibandingkan dengan kompetensi pengetahuan IPA siswa pada kelompok kontrol. Hal ini disebabkan karena model pembelajaran Time Token mendorong peserta didik untuk meningkatkan inisiatif dan partisipasinya dalam proses pembelajaran, peserta 
didik juga dilatih untuk mengungkapkan pendapatnya sehingga tidak ada peserta didik yang mendominasi. Selain itu, proses pembelajaran menjadi bertambah menyenangkan karena dibantu dengan adanya pemakaian kupon. Proses pembelajaran juga menjadi kondusif karena berbasis Tri Hita Karana, yang mengajarkan peserta didik untuk menghargai pendapat orang lain, menumbuhkan kebiasaan untuk saling mendengarkan, berbagi, memberikan masukan, dan memiliki sikap keterbukaan terhadap kritik. Hal tersebut dapat menimbulkan dan meningkatkan rasa semangat siswa dalam mengikuti pembelajaran. Sehingga siswa dapat memperdalam pemahamannya mengenai materi pembelajaran dan akan meningkatkan kompetensi pengetahuan IPA siswa.

Berbeda pada kelompok kontrol, kegiatan pembelajaran yang hanya menggunkaan pendekatan saintifik berjalan kurang optimal. Hal ini disebabkan siswa yang kurang diberikan peranan dalam proses pembelajaran karena segala sesuatunya lebih banyak mendominasi pada guru sehingga siswa masih susah mengingat dan memahami sesuatu yang mereka terima.

\section{SIMPULAN}

Berdasarkan hasil analisis statistik deskriptif kompetensi pengetahuan IPA pada kelompok kontrol diperoleh nilai rata-rata gain skor, $=0,290$. Rata-rata gain skor kompetensi pengetahuan IPA tersebut kemudian dianalisis atau dikonversikan kedalam kriteria gain skor, sehingga dapat diketahui kompetensi pengetahuan IPA siswa kelompok kontrol berada pada kategori rendah.

Terdapat perbedaan yang signifikan kompetensi pengetahuan IPA antara kelompok siswa yang dibelajarkan melalui model pembelajaran Time Token berbasis Tri Hita Karana dengan yang dibelajarkan melalui pembelajaran konvensional siswa kelas IV SDN Gugus Dewi Sartika. Hal ini terbukti dari hasil analisis uji t diperoleh thitung $=3,813$. Harga tersebut kemudian dibandingkan dengan harga ttabel dengan $\mathrm{dk}=67$ dan taraf signifikansi $5 \%$ sehingga diperoleh ttabel $=2,000$. Karena thitung $=3,813>$ ttabel $=2,000$ maka $\mathrm{Ho}$ diterima. Rata-rata kompetensi pengetahuan IPA siswa kelompok eksperimen 1=0,412 > $2=0,290$ rata-rata kompetensi pengetahuan IPA kelompok kontrol, sehingga dapat disimpulkan bahwa model pembelajaran Time Token berbasis Tri Hita Karana berpengaruh terhadap kompetensi pengetahuan IPA siswa kelas IV SDN Gugus Dewi Sartika.

Kepada guru, Berdasarkan temuan penelitian yang diperoleh, disarankan kepada guru agar lebih kreatif dan inovatif untuk memberikan fasilitas berupa sumber belajar dan kesempatan yang lebih besar bagi siswa pada pembelajaran dengan menggunakan model pembelajaran Time Token berbasis Tri Hita Karana sehingga tercipta pembelajaran kondusif dan bermakna bagi siswa. Kepada kepala sekolah, Berdasarkan temuan penelitian, disarankan kepada kepala sekolah agar dapat menggunakan hasil penelitian ini sebagai pendukung sumber belajar guru dalam meningkatkan kualitas pembelajaran sehingga sekolah mampu menghasilkan siswa yang memiliki output berkualitas.

Daftar Pustaka

Agung, A.A Gede. 2011. Pengantar Evaluasi Pendidikan. Singaraja: Universitas Pendidikan Ganesha. 
Agung, A.A Gede. 2013. Evaluasi Pendidikan. Singaraja: Universitas Pendidikan Ganesha.

Agung, A.A Gede. 2014.Metodologi Penelitian Pendidikan. Singaraja: Universitas Pendidikan Ganesha.

Anjani, Putu Sri. 2017. "Model Pembelajaran Student Teams Achievement Devisions Berbasis Tri Hita Karana Berpengaruh Terhadap Kompetensi Pengetahuan IPA". eJournal PGSD Universitas Pendidikan Ganesha Jurusna PGSD Volume 5 No: 2 (hlm.1-11).

Anjarsari, Km. Yungki. 2017. "Pengaruh Model Pembelajaran Talking Chips Berbasis Tri Hita Karana Terhadap Kompetensi Pengetahuan OPS". e-Journal PGSD Universitas Pendidikan Ganesha Jurusan PGSD Volume 5 No: 2 (hlm.1-11).

Arikunto, Suharsimi. 2015. Dasar-Dasar Evaluasi Pendidikan. Jakarta: Pt Bumi Aksara.

Atmaja, dkk. 2010. Etika Hindu. Surabaya: Paramita.

Chotimah, Chusnul dan Muhammad Fathurrohman. 2018. Paradigma BaruSistem Pembelajaran. Yogyakarta: Ar-Ruzz Media.

Dantes, N. 2017. Desain Eksperimen Dan Analisis Data. Depok: PT. Rajagrafindo Persada.

Hikmawati, Fenti. 2017. Metodologi Penelitian. Depok: PT. Rajagrafindo Persada.

Kosasih. 2016. Strategi Belajar dan Pembelajaran.Bandung : Yrama Widya.

Kurniasih, Imas dan Berlin Sani. 2016. Ragam Pengembangan Model Pembelajaran Untuk Meningkatkan Profesionalitas Guru. Surabaya: Kata Pena.

Ningzaswati, Dwi Ratna. 2015. "Pengaruh Model Pembelajaran Kooperatif Teknik Time Token Terhadap Aktivitas Belajar Dan Hasil Belajar IPA Siswa Kelas VI SD". eJournal Program Pasca sarjana Universitas Pendidikan Ganesha Program Studi Pendidikan Dasar Volume 5 (hlm.1-12).

Rosmala, Amelian dan Isrok'Atun. 2018. Model-Model Pembelajaran Matematika. Jakarta: PT Bumi Aksara.

Setyosari, Punaji. 2015. Metode Penelitian Pendidikan \& Pengembangan. Jakarta: Prenanda Media Group.

Sudaryono. 2016. Metode Penelitian Pendidikan. Jakarta: Prenadamedia Group.

Sudijono, Anas. 2015. Pengantar Evaluasi Pendidikan. Jakarta. PT. Rajagrafindo Persada.

Sugiyono, 2015. Metode Penelitian Pendidikan. Bandung: Alfabeta.

Sugiyono, 2017. Statistika Untuk Penelitian. Bandung. Alfabeta.

Sulistyowati, Eka dan Asih Widi Wisudawati. 2017. Metodelogi Pembelajaran IPA .Jakarta: Bumi Aksara.

Suryanni, dkk.2014. Pendidikan Agama Hindu Di Perguruan Tinggi. Denpasar: Udayana University Press.

Susanto, Ahmad. 2015. Teori Belajar \& Pembelajaran di Sekolah Dasar. Jakarta: Prenadamedia Group.

Wiana, I Ketut.2007. Tri Hita Karana Menurut Konsep Hindu. Surabaya: Paramita.

Wirawan, I Made Adi. 2015. Tri Hita Karana. Surabaya: Paramita 